TITLE:

\title{
Synchronization of excitatory neurons with strongly heterogeneous phase response
}

$\operatorname{AUTHOR}(\mathrm{S})$ :

CITATION:

Synchronization of excitatory neurons with strongly heterogeneous phase response. 物性 研究 2007, 87(4): 612-612

ISSUE DATE:

2007-01-20

URL:

http://hdl.handle.net/2433/110715

RIGHT: 


\title{
Synchronization of excitatory neurons with strongly heterogeneous phase response
}

\author{
Yasuhiro Tsubo, Jun-nosuke Teramae, and Tomoki Fukai \\ Laboratory for Neural Circuit Theory, RIKEN BSI \\ E-mail: tsubo@brain.riken.jp
}

大脳皮質神経細胞の同期発火現象は，脳の高次機能において重要な役割を果 たすと考えられている．同期発火現象は神経系の回路構造とともに，位相応答 などの神経細胞固有の性質によって影響を受ける．現在までの研究から，興奮 性神経細胞である錐体細胞の位相応答は，あるクラスの関数で記述されること，

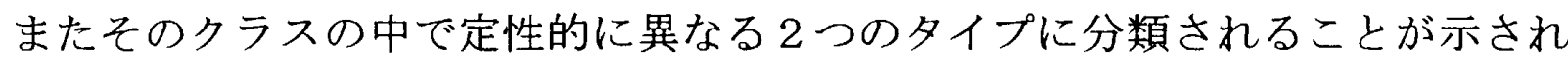
てきた. 我々の最近の研究から，錐体細胞の位相応答はその細胞が属する層（場 所）に依存してそのタイプが異なることがわかった。ささら，同じ層に属する 錐体細胞であっても，その位相応答の形は同じタイプでも均質ではなく不均質 な性質をもつことがわかった。このように，神経細胞の位相応答は不均質であ ると考えられるが，不均質な位相応答をもつ振動子集団がどのような挙動を示 すのかは，明確にはわかっていない。

そこで, 我々は不均質な位相応答をもつ振動子集団の挙動を, 大域的にパル ス結合された位相振動子モデルを用いて，解析的, 数值的に調べた. その結果, 均質な場合に同期傾向が強い位相応答をもつ振動子は，不均質にした場合に集 団は同期，部分同期，非同期と転移した。一方で均質な場合に同期傾向が弱い 位相応答をもつ振動子は，不均質性が少しでも存在すると，同期状態から部分 同期を経ずに突然非同期状態へ転移することがわかった. 